\title{
THE KATINGAN CONSERVATION PROGRAM FOR BORNEO AS A SUSTAINABLE DEVELOPMENT STRATEGY AT KATINGAN REGENCY, CENTRAL KALIMANTAN, INDONESIA
}

\author{
SYAMSURI. \\ Faculty of Social and Political Sciences, University of Palangka Raya \\ syam_najwa@yahoo.co.id
}

\begin{abstract}
The largets capital of development is sourced from natural resources, therefore, to guarantee the continuous development, the management of natural resources and environment should be carried out professionally and wisely while still taking into account the conditions of the environment and available natural resources in accordance with the concept of sustainable development. The sustainable development strategy in the Katingan Conservation program for Borneo is an effort to improve development through improving the economy and people's welfare while maintaining the preservation of natural resources and the environment. The purpose of this paper is to describe and analyze a sustainable development strategy model through the Katingan Conservation Program for Borneo in Katingan Regency, Central Kalimantan. With a qualitative descriptive approach where data collection is carried out by observation, interviews and documentation, the results of the research show that the strategy concept undertaken is through environmental sustainability strategies, economic sustainability strategies and socio-cultural sustainability strategies.
\end{abstract}

Keywords: sustainable development, conservation of natural resources and environment.

\section{INTRODUCTION}

Development is an effort made to improve the needs of the present and future society by utilizing existing resources effectively, efficiently, proportionally and equitably, especially towards the environment. Natural resources as the main source of development must be managed properly so that sustainability can be maintained. In the Brundtland Report from the United Nations, 1987 it has been stated that sustainable development is a principle development process to meet current needs without compromising the needs of future generations.

However, the occurrence of natural disasters such as land fires, floods, volcanic eruptions and so on, will be directly or indirectly affected to the increasingly reduced potential and environmental quality, thus, affect the situation and the need for development that exploiting (uncontrolled) natural resources. This is characterized by environmental imbalances, decreased natural carrying capacity, climate change and erratic weather, and environmental conflicts. This condition then leads to a domino (repressive) impact on the lives of living things on earth (environment).

Based on data from the Forum for the Environment (WALHI) that in 2015 there were 11,996.22 Ha of Forests and Land experiencing fires which then caused air pollution with an average Particulate of 10 / PM10 estimated at 1,800 in the period August-October 2015. This condition also led to problems include health, mobility and transportation, education to the economy. Then the deforestation area is also caused by investment policies and regional development. The latest data showed that the land 
controlled by the corporation was recorded at $15,356,800 \mathrm{Ha}, 83.76 \%$ or $\pm 12,862,855.7$ Ha. Katingan Regency has an administrative area of $17,800 \mathrm{~km} 2$ consisting of $13 \mathrm{sub}-$ districts and 154 villages with a population of 162,837 people if not managed properly by conservative approach, there will be significant problems with the destruction of forests and existing ecosystems.

Based on the above situations, it is necessary to create a policy to overcome and protect the environment and preserve the existing natural resources, so that they can be utilized sustainably, and can be done by a conservation program. This program does not mean eliminating the rights of the surrounding community as the owner of the area, but they can still utilize the natural resources that exist around the area to meet their needs and improve the welfare of their communities wisely and wisely while paying attention to its conservation and sustainability.

The aim of Katingan Conservation for Borneo is to create sustainable development and improve the economy and welfare of the people while still paying attention and maintaining the importance of Katingan Regency as a biodiversity storage area, the world's lungs, water sources for various interests, and as an important example of the Kalimantan region's ecosystem that has not been disturbed. The program is part of the strategy of Sustainable Development which is carried out in order to preserve the environment and the natural balance that gives benefit for the development as well as the continuity of living things. Therefore, this study will elaborate and analyze the sustainable development strategy through the Katingan Conservation program for Borneo in Katingan Regency.

\section{RESEARCH METHODS}

Researcher used a qualitative descriptive approach in finding and analyzing data in this recent study. In-depth data is collected from informants who are considered to know, understand and participate in the implementation of the program (purposiv method) through this approach. To obtain complete data, the researcher use data collection techniques through observation, interviews and documents. It was continued by data analysis using interactive model data analysis techniques with the stage of data reduction, data display (data display), and conclusions.

\section{RESULTS AND DISCUSSION}

Development is a planned and directed process in order to meet the needs of the community through various development activities by taking into account the ability and availability of resources as one of the important aspects which is then inherent to the concept of Sustainable Development so that no part is being sacrificed in the development process, because development should be an effort made to achieve a better pattern of life in society (Nia, et.al., 2009: 161). In line with the above objectives, Salim (1990) suggests that sustainable development aims to improve the welfare of the community, meet human needs and aspirations. 
In achieving the goals of a development, it is necessary to have a mechanism, tools and a wise strategy so the objective of a development can be realized. In order to achieve sustainable development goals through the Katingan Conservation program, there are three strategies implemented, namely ecological sustainability strategies, econoimical sustainability strategies and social-cultural sustainability strategies. It is in line with the previous study from Susiana (2015) that suggests the concept of sustainable development needs to connect three development paradigms, which are economic, social and environmental context.

\section{A. Environmental Sustainability Strategy (Ecological Sustainability)}

The sustainable development strategy that maintaining environmental sustainability is one of the concerns in the Katingan Conservation program for Borneo. The program is trying to maintain the existence and natural wealth owned to meet the needs and welfare of the people proportionally and directed, especially in realizing the goals of Katingan Smart, Healthy and Open. This is in line with the concept of ecological sustainability expressed by Djajadiningrat (1992) that stated ecological sustainability aims to guarantee the existence of the existence of the earth, so that there is need for action, maintenance policies. These efforts can be in the form of increasing the carrying capacity, assimilation power, and the sustainability of the use of renewable resources. Another study from Erwin (2015) added that conservation of natural resources can be done through the protection of life support systems, preservation of falura diversity and fauna and their ecosystems and sustainable use of natural resources.

The form of the program carried out in this strategy is to map and protect the area and provide assurance of space use and investment plans, develop and implement environmental rehabilitation programs, especially the recovery of the functions of Bukit Baka and Bukit Raya National Park (TNBBBR), Sebangau National Park (TNS), community-based protected forests, improve environmental management and control of environmental damage and pollution, increase community capacity in managing biodiversity resources, as well as collaborative policies on environmental awareness.

Based on the mapping carried out on protected forest areas that are included in national parks, the government of Katingan Regency sets the Bukit Raya-Bukit Baka and Sebangau National Parks as areas that cannot be used for industry, plantations and mining. As stated by Fauzi (2004), the concept of sustainability through an environmental sustainability approach is an environmentally sustainable system that must be able to maintain constant resources, avoid exploitation of natural resources and function of environmental absorption. This concept also concerns the maintenance of biodiversity, the stability of air space, and other ecosystem functions that are not included in the economic sources category.

Moreover, the government also develops ecotourism according to the uniqueness of the region, such as created the Botanical Gardens in Bukit Batu area and the establishment and preservation of local wisdom which has long been maintained 
by local communities as sites and sites that must be maintained. Local wisdom that is owned by the community is as part of the effort to maintain the sustainable environment.

\section{B. Economic Strategy (Economic Sustainability)}

A development approach with a pattern of economic sustainability is an effort to ensure economic progress in the concept of sustainability and to direct existing activities appropriately. This is what will then be achieved in sustainable development in Katingan Conservation for Borneo. Communities nearby the conservation area can still utilize the available resources as long as not damage the environment by implementing conservation awareness. The utilization of natural resources is not only to meet the consumptive needs of the local community but also the government (and the community) by develop tourist destinations, such as Bukit Batu natural tourism, climbing tours at both National Parks of Bukit Raya and Bukit Bulan in the South, as well as Riam Mangkikit tourism destination. In addition, cultural tourism is also being developed, such as mass Tiwah ritual and mamapas lewu festive. Those activities will directly or indirectly increase the income of the surrounding community.

Another strategy that is done is develop the creative industries of the community, including the fields of agro-industry and agribusiness, such as processed rattan and handicrafts and other commodities. According to Fauzi (2004), economic sustainability is a development that is able to produce goods and services continuously to maintain the sustainability of government and avoid the occurrence of sectoral imbalances that can damage agricultural and industrial production. In this regard, the government has an obligation to facilitate and advocate through the provision of funding, infrastructure development, promotion such as on the website.

In order to accelerate the implementation of the program, the government also cooperates with private sector nearby the conservation areas, such as Ulin Forest in the area of PT. Dwima Jaya Utama, Bukit Bakaka Protection Forest at PT. Hutan Mulya and Fruit Endemic Forest at PT. Fitamaya Asmapara. The form of involvement undertaken is to build infrastructure towards existing conservation areas such as road construction, provision of transportation equipment for the community and assistance in the construction of village infrastructure and facilities. The involvement of the private sector in the program not only participates in conservation programs but also by open access for the community which will then have an impact on economic growth and passion and other social development.

\section{Socio-cultural Sustainability Strategy}

The flow of globalization and modernization that is difficult to stem is a big challenge for the region and society, because it will have an impact on the sociocultural conditions of the community. The Katingan Conservation program for Borneo does not anti-globalization and modernization, but it is suggest on how the sociocultural activities of local communities as a local wisdom can support the development of the community is maintained and sustainable. Therefore, this program is not only 
limited to Conservation Areas but also relates to the social and cultural dimensions of the region as well as cultural conservation so that there is no extinction in the social and cultural patterns of society. Socio-cultural sustainability is not only seen from the aspect of sustainability value alone, but also to the stability of society, patterns of interaction and fulfillment of basic needs, maintenance of cultural elements and participation of local communities and the role of the private sector. The Universal Declaration of Cultural Diversity (UNESCO, 2001) explores the concept of sustainable development by stating that cultural diversity is important to humans as well as the importance of biodiversity for nature. Thus, development is not only understood as economic development, but also as a tool to achieve intellectual, emotional, moral, and spiritual satisfaction.

The government as an element that has formal power to maintain and maintain the socio-cultural community also seeks to see the unique potential of community culture that can be developed into a special attraction for tourists. The efforts made were inventorying sites and cultural heritage and establishing existing Customary Forest areas by the government along with communities, traditional leaders and religious leaders to be used as protected and preserved cultural heritage. Then preserve local wisdom that is held for generations such as tajahan, kaleka, sapundu, pahewan and patahu. Another strategy that is also carried out is by increasing the role of the surrounding community and the private sector, especially companies around the region. In addition, the government continues to make persuasive efforts to increase community participation, namely through various activities, including festivals, rituals, or cultural activities and involving them in the policy process.

\section{CONCLUSION}

The sustainable development strategy carried out in the Katingan Conservation Program for Borneo in Katingan Regency through the Environmental, Economic and Socio-cultural approaches is as a program that is not only to improve the economy and welfare of the community but also as an effort to protect and conserve natural and environmental resources continuously. The environmental sustainability strategy is carried out by establish restriction on plantation or mining industry in conservation areas, such as Bukit Baka National Park and Bukit Raya (TNBBBR) and Sebangau National Park (TNS). The economic sustainability strategy is carried out by developing natural tourism destinations, cultural tourism, developing creative industries by utilizing local potential and developing infrastructure supporting the economic activities of the community. The socio-cultural sustainability strategy is carried out by protecting and preserving sites and cultural heritage, preserving local wisdom and establishing Customary Forest areas and persuasive efforts through local festival activities and traditional rituals. Through this program, it is expected that the ecosystem and the survival of living things, both flora, fauna and humans themselves as actors and connoisseurs of a development remain balanced and the sustainability 
between development, natural resources and the environment is created, thus delivers benefit to the society.

\section{REFERENCE}

Ardani, Muh. 2004. Dilemma development and challenges. Yogyakarta;Pustaka

Pelajar.

Barca, Fabrizio. Et al. 2012. The Case For Regional Development Intervention:Place-Based Versus Place-Neutral Approaches. Journal of Regional Science, vol. 52, no. 1, 2012, pp. 134-152.

Basaraba dan Mariciuc. 2010. Local Development Strategies - Regional Policy Tools In Romania. Study Case: Valea Jiului Microregion. Studia Universitatis Babeş-Bolyai, Studia Europaea, LV, 1, 2010.

Creswell, Jhon W. 2010. Research Design: Qualitative, Quantitative and Mixed Methods Approaches. terjemahan oleh Achmad Fawaid Research Design : Pendekatan Kualitatif, Kuantitatif, dan Mixed. Pustaka Pelajar.

Daly, Herman. 1990. "Commentary: Toward some operational principles of sustainable development." Ecological Economics 2 (1990).

Griggs, D. 2013. From MDGs to SDGs: Key challenges and opportunities. Jerman: Monash Sustainability Institute.

http://sustainabledevelopment.un.org/content/documents/3490griggs.p $\mathrm{df}$

Hirschman, Albert. 1958. The Strategy Of Economic Development. New Heaven, Oxport University Press. Inc.

Ife, Jim. 1997. Community Development,: Creating Community Alternatives-Vision, Analysis and Practice. Melbourne: Addison Wesley Longman.

JICA. Capacity Development Handbook for JICA Staff. March 2004.

Kuncoro, Mudrajad, 2004. Regional Autonomy and Development: Reform, Planning, Strategy and Opportunities. Jakarta: Erlangga.

Miles, Matthew B \& A. Michael Huberman, 2014, Qualitative data analysis: a methods sourcebook. Edition 3. SAGE Publications, Inc. Thousand Oaks, Califponia 91320.

Suryono. Agus. 2010. The Prima Dimensions of Development Theory. UB Press.

Susiana, Sali. 2015. Sustainable development; socioeconomic and environmental dimensions. Jakarta. Azza Grafika

United Nation Development Programme (UNDP), 2002, Human Development Report 2002 -Deepening Democracy in a Fragmented World, Oxford, New York. 
Wibawa. Samodra. 1991. Sustainable development process related to socioeconomic and political development in Indonesia. Tiara Wacana Yogya.

World Business Council for Sustainable Development (WBCSD), 2002, Sustainable Development Reporting - Striking a Balance, WBCSD Report, Atar Roro Presse, Switzerland.

World Commission on Environment and Development (WCED), 1987, Our Common Future, Oxford University Press, Oxford. 